\title{
Inequality and the social environment: a reply to Lynch et al
}

The paper by Lynch et $a l^{1}$ is intended to cast doubt on the importance to health of social capital, relative income and psychosocial pathways, and to gain support for a view of the continued importance of absolute income and of "neomaterial" factors.

Before answering specific points I should draw attention to two new studies that support the importance of relative income over absolute income in richer countries. Firstly, data for 21 regions of Taiwan showed that, as living standards rose during the course of rapid economic growth, income inequality replaced absolute median income as the best predictor of mortality. ${ }^{2}$ Secondly, in an analysis of infant mortality in relation to income distribution and gross national product per capita (GNPpc) in three sets of data covering richer and poorer countries, Hales et al $l^{3}$ showed that income distribution was more important than GNPpc except in the poorer countries.

\section{Relative and absolute income}

Lynch et al show a positive correlation between life expectancy and gross domestic product per capita (GDPpc) in member countries of the Organisation for Economic Cooperation and Development (OECD) where I had shown none. ${ }^{4}$ Their evidence misses the point. The difference arises because OECD has added new and poorer members. As I have emphasised, absolute living standards are important in poorer countries. Thus, if we take combined male and female life expectancy in relation to GDPpc at purchasing power parities among the richest 21 countries in $1995,{ }^{5}$ instead of finding the positive correlation reported by Lynch et al, there is a weak negative one $(r=-0.11)$. Alternatively, taking just the 23 countries with the highest life expectancy (74 years or above), the correlation between GDPpc and life expectancy is also nonexistent $(r=0.08)$. The positive correlation reported by Lynch et al therefore results wholly from the inclusion of some poorer countries - where we all agree absolute standards continue to make a difference. But it is no guide to the situation in the most affluent nations.

My desire is not simply to point out that the richest countries do not seem to gain much by consuming an ever increasing proportion of the world's scarce resources. The problem with measures of economic growth and GDPpc is that the undifferentiated bundle of goods and "bads" that economic growth brings with it does little for health. We need to be more discriminating about the content of growth. With rapidly growing obesity rates, high rates of road fatalities and increasing concern over air pollution, it is surprising that Lynch et al choose higher rates of car ownership as an example of the way material factors continue to benefit health-particularly when they are ultimately trying to explain not individual differences in health but aggregate population health. While there are undoubtedly important ways in which material life could be changed to produce better health, it is clear that much of what passes for economic growth in the most affluent parts of the world is of little benefit-as the various "Measures of Economic Welfare" show only too clearly. ${ }^{6}$

Continuing with the issue of relative versus absolute income, Lynch et al also refer to an earlier paper demonstrating a close relation between income inequality and mortality in the 282 Standard Metropolitan Areas (SMAs) of the USA. ${ }^{7}$ They suggest that the weaker relation shown in that paper between median income and mortality in the SMAs was an indication of the importance of abso- lute income. But if that is true, why are the large differences in the absolute median incomes of the 50 US states not also related to mortality? (The correlation of only $r=-0.26$ between state median income and mortality disappears altogether after controlling for income distribution. ${ }^{8}$ ) Because some SMAs are small-with populations going down to 57000 - what is happening is surely that median income starts to pick up on the relative deprivation of an area in relation to the wider society. As I have pointed out, ${ }^{9}$ people in deprived neighbourhoods do not have bad health because of inequalities within the neighbourhood, but because the whole neighbourhood is deprived in relation to the wider society. In general, as you move from larger to smaller areas, median income becomes a more important predictor, and income distribution a weaker predictor, of mortality. Both imply that the burden of low relative income is important, and can be measured either within large areas or between economically segregated small areas. $^{10}$

\section{Social capital}

Now for the difficult issue of social capital. I strongly agree with Lynch et al when they say that "Overly simplistic interpretations of the links among social capital, economic development, public policy and health ...may do a disservice to a progressive agenda for greater social justice and better public health." However, they are tarred by their own brush: their criticisms are wholly based on the simplistic interpretations that do nothing to develop our insights. Part of the difficulty with the concept of social capital is that it was borrowed from other disciplines rather than being developed specifically for the health field. Instead of importing the concept wholesale, we need to think what might lie behind it that could affect health. No doubt it is a popular concept because it holds out the idea that there are costless ways of making society and the economy work better-implying that poor communities can pull themselves up by the boot-straps without extra money. But an important part of the growing health interest in social capital comes not from ignoring income distribution, but precisely from the opposite direction: from trying to understand why income distribution is important to health.

Here the evidence clearly suggests that more egalitarian societies are more cohesive ${ }^{11}{ }^{12}$ - less violent, lower homicide rates, ${ }^{13}$ more trust, ${ }^{14}$ lower hostility scores, ${ }^{15}{ }^{16}$ and more involvement in community life. ${ }^{17}$ The evidence is strong: indeed, a meta-analysis of some 34 studies suggests that the tendency for violence rates to be lower where income differences are smaller is robust. ${ }^{13}$ In his study of the Italian regions, Putnam, talking of more egalitarian social attitudes, said that "equality is an essential feature of (a stronger) civic community" (page 105). ${ }^{17}$ Against all this, Lynch et al say (as if wanting to prove that inequity is not divisive) that, among a group of 15 developed countries, measures of social capital-such as voluntary work - are more strongly related to GNPpc than to income distribution. This is hardly surprising when, at the poor end of their 15 developed countries, they include Poland, Hungary and the Czech Republic-well known for having not only a much lower GNPpc but also a voluntary sector that has only been able to start developing over the past decade.

Rather than conceiving of social capital as a factor of production like financial capital, or believing that greater equality represents nothing more than a fairer share out of 
the spoils of economic activity between self interested individuals, the evidence suggests that a fuller understanding of the relation between income inequality and social cohesion has more in common with the early socialist belief that inequality was an obstacle to greater human harmony. Nevertheless, Lynch et al are right to be worried that people can, and do, form cohesive groups that exclude and discriminate against others. As Adam Smith pointed out, an association of merchants is a conspiracy against the public, and none can fail to be aware of the dangers of discrimination against, and victimisation of, racial, ethnic, and other vulnerable minorities. But to recognise that groups can come together against others is not an argument against trying to reduce social divisions by reducing economic inequality. Although people can be united in opposition to others, that does not mean that reducing economic divisions improves social cohesion by feeding into divisive processes of that kind. Indeed, the reverse is true. If one gives some thought to the processes of social discrimination and their relation to differentials in economic status and issues of inferiority, etc, it is much more likely that reducing income differentials also reduces the dangers of discrimination against minorities. Lynch et al have conflated the crucial issues. It is not by chance that extreme racist and nationalist groups seem to flourish in times of high unemployment and difficult economic conditions. Indeed, in The authoritarian personality, ${ }^{18}$ which Adorno et al (1950) wrote to try to account for the horrors of the Nazi regime, he describes how people at each layer in status hierarchies are servile to those above while "kicking down" at the more vulnerable groups below them. Recent research findings from those working on the way social cohesion may mediate between income distribution and mortality actually demonstrate that greater income inequality is associated with increased racial prejudice. ${ }^{19}$ The likelihood is then that if we fail to reduce income inequalities societies will be more likely to show tendencies towards discrimination and victimisation of vulnerable groups. By reducing inequality we increase cohesion partly by reducing some of what fuels these social divisions.

\section{Psychosocial pathways}

Trower et al introduced the idea that there are two basic forms of social organisation among human and nonhuman primates: "agonistic" societies based on dominance hierarchies, and "hedonic" societies based on egalitarian cooperation (as typified among humans by hunter-gather societies ${ }^{20}$ ). There is clearly a stark contrast between dominance hierarchies, or pecking orders, in which power and coercion provide access to resources regardless of other's needs, and societies with more cooperative social relations, in which people's needs are recognised and mediated through the social obligations of sharing and reciprocity - as between friends. Indeed, the tendency for the quality of social relations to be marked by more violence, hostility and mistrust where inequality is greater, seems likely to reflect a shift in the balance between these two fundamental forms of human association. The more sociable strategies appropriate to more egalitarian and cooperative societies are driven out by the increasing emphasis on hierarchical relations of dominance and subordination.

If it is true that social relations tend to atrophy in a more hierarchical society, then the implications for health could hardly be clearer. Social affiliations and friendship networks appear highly protective of health, just as low social status is linked to worse health. Twofold and threefold differences in mortality have been reported between the high and low ends of each, and the frequency of exposure to these risk factors means that the population attrib- utable risks are very substantial. If an increase in the scale of the problem of low social status is accompanied by an atrophying of social relations, it would be odd if health was not harmed.

Viewed in this context there are surely clues as to why friendship and low social status are important to health. Although they are clearly quite different variables, they may be important for the same reason. That is to say they may both tap into the extent to which people are subservient to agonistic power relations and/or enjoy more mutually supportive social interactions. There are good reasons for thinking that these dimensions of social reality may have a special salience as determinants of levels of anxiety and physiological arousal in a population. Because members of the same species have all the same needs there is a potential for continuous conflict between them. But as well as being each other's most feared rivals, human beings can also be the greatest source of assistance, support, care, learning and love. The nature of social relations must have been crucial to welfare and survival throughout human evolution.

Although some still wish to deny that there is an important psychosocial component in the health effects of low social status, it is harder to reject psychosocial explanations of the effects of social affiliation. A material explanation of the health advantages of friendship would be plausible if poor people had close friends who could lend them large sums of money when they were behind with the rent or whatever; but most poor people have poor friends. The list of what friends really give each other includes alcoholic drinks, cigarettes, infections and possibly AIDS - hardly an explanation of the health benefits of friendship. However, when it comes to the health effects of low social status, it is very much easier to find possible material factors that may, and often do, have direct health effects. But there is also evidence that there are, additionally, very important psychosocial pathways through which people's circumstances effect their health. For example, the work on job insecurity shows that health worsens when jobs first become insecure and people start worrying-long before they actually become unemployed. ${ }^{21}$ The same is true of the importance of being in control of your work or home circumstances. ${ }^{22}{ }^{23}$ Similarly, when Shively reported a fivefold increase in atherosclerosis among monkeys who moved down the hierarchy as a result of experimental manipulations of social status, the fact that diet and the environment were controlled pretty well ruled out all but psychosocial explanations. That social rank may, as Lynch et al suggest, be a weak predictor of individual differences in psychosocial markers, does not mean that it is not a good predictor of differences between groups ranked by social status $^{24}$ : social class differences in mortality do after all account for a very small part of the individual differences in age of death. ${ }^{25}$ Similarities between some of the physiological effects of low social status produced under experimental conditions in monkeys and those associated with social status among human beings ${ }^{26}$ suggests that an important part of the social gradient in human health is attributable to the direct effects of social status rather than to other influences on health like poorer housing, diet and air pollution. Suggestions have been made elsewhere about the possible role of issues of inferiority and disrespect. ${ }^{27} \mathrm{I}$ have discussed many of these points more fully elsewhere. ${ }^{28} 29$

The answer to the question posed by the title of the article by Lynch et al - as to whether social capital is a good investment for public health - is that it depends on how it is to be increased.

RICHARD G WILKINSON

Trafford Centre for Medical Research, University of Sussex, Brighton BN19RY (R.G.Wilkinson@sussex.ac.uk) 
1 Lynch J, Due P, Muntaner C, et al. Social capital-Is it a good investment strategy for public health? F Epidemiol Community Health 2000;54:404-8. 2 Chiang T-L. Economic transition and changing relation between income inequality and mortality in Taiwan: regression analysis. BMF 1999;319: $1162-5$.

3 Hales S, Howden-Chapman P, Salmond C, et al. National infant mortality rates in relation to gross national product and distribution of income. Lancet 1999;354:2047.

4 Wilkinson RG. Health inequalities: relative or absolute material standards? BMF 1997;314:591-5. (Reprinted in: Income inequality and health. loc cit.) 5 OECD Health Data 99. CD ROM.

6 Daley HE, Cobb JB. For the common good. London: Green Print, 1990

7 Lynch J, Kaplan GA, Pamuk ER, et al. Income inequality and mortality in metropolitan areas of the United States Am F Public Health 1998;88:107480. (Reprinted in: Income inequality and health loc cit.)

8 Kaplan GA, Pamuk E, Lynch JW, et al. Inequality in income and mortality in the United States: analysis of mortality and potential pathways. $B M \mathcal{F}$ 1996;312: 999-1003. (Reprinted in: Income inequality and health. loc cit.)

9 Wilkinson RG. Income, inequality and social cohesion Am 7 Public Health 1997;87: 104-6.

10 Franzini L, Ribble J, Spears W. Correlations between mortality, median income, and income inequality vary by population size in Texas counties. income, and income inequality

11 Kawachi I, Kennedy B, Wilkinson RG, eds. Income inequality and health. The Society and Population Health Reader vol 1. New York: New Press, 1999.

12 Wilkinson RG. Unhealthy societies: the afflictions of inequality. London: Routledge, 1996

13 Hsieh CC, Pugh MD. Poverty, income inequality, and violent crime: a metanalysis of recent aggregate data studies. Criminal fustice Review 1993;18:182-202. (Reprinted in: Income inequality and health. loc cit.)

14 Kawachi I, Kennedy BP, Lochner K, et al. Social capital, income inequality and mortality. Am f Public Health 1997;87:1491-8. (Reprinted in: Income inequality and health. loc cit.)

15 Williams RB, Feaganes J, Barefoot JC. Hostility and death rates in 10 US cities Psychosom Med 1995;57:94.

16 Wilkinson RG. Health, hierarchy and social anxiety. In: Adler NE, Marmot M, McEwen BS, et al, eds. Socioeconomic status and health in industrial nations: social, psychological and biological pathways. Ann NY Acad Sci 1999;896:48-63.
17 Putnam RD, Leonardi R, Nanetti RY. Making democracy work: civic traditions in modern Italy. Princeton: Princeton University Press, 1993.

18 Adorno TW, Frenkel-Brunswik E, Levinson DJ, et al. The Authoritarian Personality. New York: Harper, 1950

19 Kennedy BP, Kawachi I, Lochner K, et al. (Dis)respect and black mortality. Ethn Dis 1997;7:207-14. (Reprinted in: Income inequality and health. loc cit.)

20 Trower P, Gilbert P, Sherling G. Social anxiety, evolution and selfpresentation. In: Leitenberg $\mathrm{H}$, ed. Handbook of social and evaluation anxipresentation. In: Leitenberg H, ed. Handb.
ety. New York: Plenum Press, 1990:11-45.

21 Ferrie JE, Shipley MJ, Marmot MG, et al. An uncertain future: the health effects of threats to employment security in white collar men and women. Am F Public Health 1998;88: 1030-6.

22 Marmot MG, Bosma H, Hemingway H, et al. Contribution of job control and other risk factors to social variations in coronary heart disease. Lancet 1997;350:235-40.

23 Nettleton S, Burrows R. Mortgage debt, insecure home ownership and health: an exploratory analysis. Sociology of Health and Illness 1998;20:73153

24 Kristenson M, Orth-Gomer K, Kucinskiene Z, et al. Attenuated cortisol response to a standardised stress test in Lithuanian versus Swedish men: the LiVicordia Study. International fournal of Behavioural Medicine 1998;5: 17-30. (Reprinted in: Income inequality and health. loc cit.)

25 Koskinen S. Time trends in cause specific mortality by occupational class in England and Wales. In: Proceedings of IUSSP 20th General Conference (held in Florence June 1985). Florence: IUSSP, 1988.

26 Brunner E, Marmot M. Social organization, stress, and health. In: Marmot MG, Wilkinson RG, eds. The social determinants of health. Oxford: OUP, 1999.

27 Wilkinson RG, Kawachi I, Kennedy B. Mortality, the social environment, crime and violence. Sociology of Health and Illness 1998;20:578-97. (Reprinted in: Income inequality and health. loc cit.)

28 Wilkinson RG. Income inequality, social cohesion, and health: clarifying the theory-a reply to Muntaner and Lynch. Int F Health Serv 1999;29:525-43.

29 Wilkinson RG. The culture of inequality. In: Kawachi I, Kennedy B, Wilkinson RG, eds. The Society and Population Health Reader, vol 1. Income inequality and health. NewYork: New Press, 1999. 